\title{
Six Sigma and Business Environment in Nigeria
}

\author{
Dr. Suleiman, Abubakar Sadiq \\ Kaduna PolytechnicCollege Of Business And Management Studies Department Of Business \\ AdministrationKaduna, Nigeria.
}

\begin{abstract}
The Paper Addressed Six Sigma And Business Environment In Nigeria. Process Improvements Are Actions Taken For Improving Organizational Processes, The Need For Making Process Improvements Continually Is Imperative For The Survival Of Organizations Because Of The Need To Respond Rapidly To Ever-Changing Environments In The Face Of Stiff Competition. The Paper Examined The Environmental Influence On The Application Of Six Sigma Strategy In Nigeria. The Survey Method Was Adopted. The Instrument For Data Collection Was Built On A Likert-Scale System. The Questionnaire Has A Reliability Coefficient (R) Value Tested With Cronbach's Alpha Statistics. Based On The Findings Of The Paper, It Is Discovered That Six Sigma Adds Significant Value To The Organization That Adopt The Strategy. The Study Also Revealed That The Environmental Factors Positively Affect The Application Of Six Sigma Strategy In Nigeria. Six Sigma Strategy Could Be Better Implemented And Better Result Achieved When Environment Is Conducive Than When It Is Not. The Paper Recommends That Government Should Create A Conducive Business Environment For The Application Of Six Sigma. Also Managers In The Sectors Should Constantly Review Or Scan The Environment Should Be Encouraged To Avoid The Unforeseeable Troubles.
\end{abstract}

\section{Introduction}

Process Improvements Are Actions Taken For Improving Organizational Processes, The Need For Making Process Improvements Continually Is Imperative For The Survival Of Organizations Because Of The Need To Respond Rapidly To Ever-Changing Environments In The Face Of Stiff Competition (Hayes And Pisano, 1994). Six Sigma Can Be Considered Both A Business Strategy And A Science That Has The Aim Of Reducing Manufacturing And Service Costs, And Creating Significant Improvements In Customer Satisfaction And Bottom-Line Savings Through Combining Statistical And Business Process Methodologies Into An Integrated Model Of Process, Product And Service Improvement.

In Six Sigma, Customer Focus Becomes The Top Priority And Any Improvements Are Defined By Their Impact On Customer Satisfaction And Value (Pande And Neumann, 2002). From An Internal Perspective, Six Sigma Provides A Way Of Improving Processes So That The Company Can More Efficiently And Predictably Produce World-Class Products And Services.

Conceptually, Six Sigma Is Focused On Variation Reduction. If Companies Can Understand And Reduce Variation In Their Process, Then They Can Implement Improvement Initiatives That Will Stabilize The Process And Ensure Accuracy And Reliability According To The Expectation (Goeke And Offodile, 2005) While Defect Reduction Is An Element Of The Six Sigma Approach, Six Sigma Has Evolved From A Statistical Quality-Control Method To A Customer-Focused Philosophy That Challenges Organizations To Change Strategies, Focus, Internal Procedures, And Business Models. Bhuiyan And Baghel, (2005) Argued That, Continuous Process Improvement Is An Ongoing Activity Aimed At Improving Companywide Performance Through Focused Incremental Changes In Processes. The Role Of Six Sigma Has Evolved In Response To New Environmental Challenges Faced By Organizations. This Is Inconsistence With The Opinion Of (Brown And Blackmon, 2005) And (Cole, 2002) That, A Vast Increase In The Speed And Intensity Of Environmental Changes Has Resulted In Expanding The Objectives Of Continuous Improvement Initiatives. Endorsing This View, (Boer And Gersten, 2003) Assert That, Continually Improving Process Flexibility And Innovation Capabilities Now Supplement Traditional Continuous Improvement Objectives Of Increasing Efficiencies And Reducing Costs. The Paper Will Examine How The Environmental Factors Influence The Application Of Six Sigma In Nigeria.

\section{The Environment Of Business}

Business Environment Defined As The Total Of All Things External To Firms And Industries Which Affect Their Organization, Operation And Development, (Betts, 1994). These Include Social, Economic, Political, Technological, Scientific And Cultural Aspects Which, In Some Way, Influence Business. None Of These Aspects Is Completely Independent Of The Other. 


\section{Demographics}

The Demographics Of The Financial Sector And Their Target Markets Have Changed Dramatically In The Last Twenty Years And Will Continue To Change Drastically In The Next Twenty Years. This Dynamic Has Created Tremendous Untapped Opportunity That Can Translate Into Both Growth And Profitability Of Companies For Tomorrow, (Coulson, 1994). These Corporations, Many Of Which Are Publicly Traded Companies, Are Under Tremendous Pressure To Meet Corporate And Growth Goals While Delivering Financial Results That Significantly Improve Stockholder Value, (Thomas (1994).

\section{Technological Changes And Developments}

The Categories Of Innovations Under Development Span The Continuum Between Those Technologies That Attempt To Address Current Needs And Those Designed To Solve The Foreseeable Problems Of Tomorrow, (Drucker (1993). A Company's Constant Awareness Of The New Technologies On The Horizon Is Critical To Its Ongoing Improvement And Competitiveness In The Market.

Companies Who Identify And Recognize The Key Changes And Associated Issues That Would Materially Affect Their Businesses Will Be Best Positioned To React To The Changes In A Positive Way, (Drury, 1988). Technology Is A Mixed Blessing In Many Ways, A New Technology May Improve Our Life In One Area, While Creating Environmental And Social Problems In Other Areas. A Few Of The Benefits From Technology Are Greater Productivity, Higher Living Standards, More Leisure Time And Greater Variety Of Products, (David, 1989).

\section{Political/Legal Environment}

Developments In The Political Environment Are Increasingly Affecting Decisions On The Business Sector. Political System Is A Broad Term, Covering The Rules And Institutions By Which A Nation Is Governed. It Consists Of An Interacting Set Of Laws, Government Agencies, And Pressure Groups That Influence And Constraint The Conduct Of Various Organizations And Individuals In The Society, (Mohammed, 1998).

Political-Legal Forces Are The Constraints On Decision Making That Result From The Legal And Otherwise Government Parameters Within Which The Firm Must, Or May Wish To Operate, (Mohammed And Tucker, 1996). The Legal Obligations That Permeate The Business Environment Are So Numerous And So Intrusive On Decision Making That Managers Must Do More Than Use Their "Good Sense" In Attempting To Act As Responsible Corporate Citizens.

\section{Economic Forces}

The Economic Environment Is Of Concern Only To Business Whose Socially Approved Mission Is The Production And Distribution Of Goods And Services That People Want And Can Pay For. But It Is Also Of The Greatest Importance To Other Types Of Organized Enterprises. A Government Agency Takes Resources, Usually From Tax Payers, And Provides Services Desired By The Public. All Organization Needs Capital Machinery, Buildings Inventories Of Goods, Office Equipment, Tools Of All Kinds, And Cash. Some Of These May Be Produced By The Organization Itself, As It Happens When A Business Builds Its Own Machinery, (David, 1989).

\section{Socio-Cultural Forces}

Culture Has Been Defined As The Complex Whole Of Man's Acquisitions Of Knowledge, Morals, Beliefs, Art, Custom, Technology, Traditions And Skills Etc. Which Are Shared And Transmitted From Generation To Generation (Freilich, 1971). The Central Reference Of This Definition Which Was Originally Proposed By Edward Tylor In 1871 Is To The Effect That Culture Means Everything Which Is All The Shared Products Of A Human Society.

Socio-Cultural Forces Affect Managers Decisions Because They Are Known To Influence The Way Customers And Other Outsider React To The Firm's Operations And Products. It Is Socio-Cultural Forces That Determine Customers' Perception Of “Good Taste” In Advertising, Employees' Views On Equal Employment Opportunity, And Competitors' Beliefs About Ethical Business Practice. Another Major Component Of The Macro-Environment Is The Cultural System. People Grow Up In A Particular Society That Shapes Their Basic Beliefs, Values And Norms, (Imaga (2000).

Toward Supporting A Dynamic Strategic Initiative For The Six Sigma Program It Is Important For The Six Sigma Infrastructure To Engage Employees In Scanning The Environment So They Can Capitalize On Any Opportunities (Crossan And Berdrow, 2003). Organizations Interact With Their Environments At Multiple Levels - Organizational, Business Unit, Department, And Process (Elenkov, 1997).

In Any Classification Of Environmental Elements Impacting On A Manager, It Is Extremely Difficult To Separate, Even For Discussion Purposes, The Social, Political And Ethical Environments. Conceptually, 
However, The Social Environment Is Made Up Of The Attitudes, Desires, Expectations, Degrees Of Intelligence And Education, Beliefs, And Customs Of People In A Given Group Or Society. The Political Environment Is Primarily That Complex Of Laws, Regulations, And Government Agencies And Their Actions Which Affect All Kinds Of Enterprises, Often To A Varying Degree, (Grant, 1996).

\section{An Analysis Of The Nigerian Business Environment}

The Environment Of A Company In Business Is The Pattern Of All The External Conditions And Influences That Affect Its Life And Growth Or Expansion. The Environmental Influences, In Relation To Long Range Business Planning, Operate In A Company's Industry, The Total Business Community, Its City, Its Country, And The Real World In Which It Has Found Itself. The Influences Are Felt In Four Directions: Technology, Economic, Social, And Political Forces. But In All These Four Directions, Changes Take Place At Varying Rates. Changes Are Often Rapid In The Direction Of Technology And Least In Political Direction In Advanced And Stable Economies, Not In Countries Like Nigeria. Changes In The Business Environment, Irrespective Of The Level Of Economic Development Of The Country, Generally Necessitate Continuous Evaluation Of A Company's Definition Of Its Business And Necessary Revision In The Scope Of Its Business Without Which A Company May Go Obsolete In Policies And Goals, (Imaga, 2000). Forecasting Of Any Sort And Degree Of Accuracy Is Indispensable To Modern Business Enterprises Of Some Worth And Standing, Organizations That Make Appropriate And Aligned Internal And External Innovations Are Successful; They Are Able To Take Advantage Of Environmental Opportunities And Survive Environmental Challenges Including Competition. Those Organizations That Fail To Update Their Routines Decline And Get Winnowed Out, (Beer Et Al., 2005).

At Any Point In Time, Dynamic Forces Are At Work, Generating Changes In The Environment. Forces Outside The Business, For Example, Government Regulation, Social Values And Culture Are In Her View Not Spared. New Products And Methods, Innovations In Management, Competition, Etc Are Changes From Within The Business. Thus, Business Firms Come And Go Under The Relentless Pressure Of Change, (Iweala, 2004).

The Environment Is The World In Which The Organization Exists And So Some View Of The Enormously Complex Set Of Variables Must Be Forged In Order To Understand The Impact Of The Environment Upon The Organization. Resources Provide The Internal Influences Upon Strategic Choice And Such An Analysis Of Resources Aims To Build A Picture Of Them. Strategic Analysis Is Not A Static Snapshot Event But A Continuous Process Sine The Strategic Choices And Their Implementation Impact Upon The Environment, Culture, And Resources Of The Organization, (Handy, (1991).

An Analysis Of The Environment Is Important Because It Increases The Quality Of Strategic Decision Making By Considering A Range Of The Relevant Features Well Before The Need To Make An Irrevocable Decision. The Organization Identifies The Threats And Opportunities Facing It And Those Factors That Might Assist In Achieving Objectives And Those That Might Act As A Barrier. The Strategy Of The Organization Should Be Directed At Exploiting The Environmental Opportunities And To Blocking Environmental Threats In A Way That Is Consistent With Internal Capabilities. This Is Competitive Position (Grant 1996).

The Need For Making Process Improvements Continually Is Imperative For The Survival Of Organizations Because Of The Need To Respond Rapidly To Ever-Changing Environments In The Face Of Stiff Competition (Hayes And Pisano, 1994). Upper Management Makes Assessments Of The Overall Business Environment And The Economy To Determine Broad Strategic Goals For The Six Sigma Program (De Feo And Barnard, 2004).

The Success Of An Environmental Analysis Is Largely Dependent Upon The Characteristics Of That Environment: The Complexity Of It; (That Is How Many Variables Are In The Environment), The Rate Of Change And The Amount (And Cost) Of Available Information About It. The Search For A New Combination Of Practices Is Initiated In Response To Changes In Environmental Demands Such As Increasing Need For Flexibility Or To Improve Internal Abilities Such As Continually Reducing Defects. The Task Environment, By Contrast, Is That Which Has A Major And Direct Impact Upon The Organization, And Its Strategic Planning Process (Konter (1985).

\section{Methodology}

Since The Perception Of Six Sigma Has Changed Drastically From Being A Statistical Tool To Being A Company-Wide Strategy For Business Process Improvement, Accurate Data Must Be Collected Directly From Such Companies And Factually Analyzed. The Data Obtained Herein Were Collected Through A Well Designed Sample Survey To Assess And Evaluate The Six Sigma And Business Environment In Nigeria. After The Actual Data Collection Process, The Data Were Classified Into Tables With Exploratory And Logical Categories For Analysis. The Statistical Package For The Social Sciences (Spss) Version 17.0 Is Hereby Employed For The Data Analysis. In The Process Of Data Analysis, A Data File Containing The Original Codes 
Of The Survey Questionnaire Were Entered Into The Spss Data Editor. Then The Creation Of Tables And Consequently Analyses Were Conducted In An Automated Manner.

III. Presentation Of Summary Statistics

The Presentations Of The Data Summaries In Form Of Frequency Tables As Well As The Analytical Tables Are As Follows

Table 1.1: Technological Environment Affects The Application Of Six Sigma Strategy In Nigeria.

\begin{tabular}{||l|ll|l||}
\hline Responses & Frequency & Percent & Cumulative Percent \\
\hline Strongly Agree & 40 & 10.5 & 10.5 \\
Agree & 228 & 60.0 & 70.5 \\
Undecided & 70 & 18.4 & 88.9 \\
Disagree & 36 & 9.5 & 98.4 \\
Strongly Disagree & 6 & 1.6 & 100.0 \\
\hline Total & 380 & 100.0 & \\
\hline
\end{tabular}

Source: Survey 2011

From Table 1.1, Particularly From The Survey Data, It Can Be Deduced That A Cumulative Of 70.5\% Of The Respondents Agreed That Technological Environment Affects The Application Of Six Sigma Strategy In Nigeria. On The Other Hand, A Cumulative Of 11.1\% Of The Respondents Disagreed With The Same Notion While $18.4 \%$ Of Them Remained Undecided.

Table 1.2: The Application Of Six Sigma Strategy Is Influenced By The Economic Environment.

\begin{tabular}{||l|ll|l||}
\hline Responses & Frequency & Percent & Cumulative Percent \\
\hline Strongly Agree & 50 & 13.2 & 13.2 \\
Agree & 214 & 56.3 & 69.5 \\
Undecided & 94 & 24.7 & 94.2 \\
Disagree & 16 & 4.2 & 98.4 \\
Strongly Disagree & 6 & 1.6 & 100.0 \\
\hline Total & 380 & 100.0 & \\
\hline
\end{tabular}

Source: Survey 2011

From Table 1.2, Particularly From The Survey Data, It Can Be Deduced That A Cumulative Of 69.5\% Of The Respondents Agreed That The Application Of Six Sigma Strategy Is Influenced By The Economic Environment. On The Other Hand, A Cumulative Of 5.8\% Of The Respondents Disagreed With The Same Notion While $24.7 \%$ Of Them Remained Undecided.

Table 1.3: The Legal Cum Political Environment In Nigeria Influences The Application Of Six Sigma Strategy.

\begin{tabular}{||l|ll|l||}
\hline Responses & Frequency & Percent & Cumulative Percent \\
\hline Strongly Agree & 55 & 14.5 & 14.5 \\
Agree & 144 & 37.9 & 52.4 \\
Undecided & 152 & 40.0 & 92.4 \\
Disagree & 25 & 6.6 & 98.9 \\
Strongly Disagree & 4 & 1.1 & 100.0 \\
\hline Total & 380 & 100.0 & \\
\hline
\end{tabular}

Source: Survey 2011

From Table 1.3, Particularly From The Survey Data, It Can Be Deduced That A Cumulative Of 52.4\% Of The Respondents Agreed That The Legal Cum Political Environment In Nigeria Influences The Application Of Six Sigma Strategy. On The Other Hand, A Cumulative Of 7.7\% Of The Respondents Disagreed With The Same Notion While $40.0 \%$ Of Them Remained Undecided.

\section{Presentation Of Descriptive Statistics}

Table 2.1: Environmental Factors Influence The Application Of Six Sigma Strategy In Nigeria:

\begin{tabular}{|c|c|c|c|c|}
\hline Responses & $\mathrm{N}$ & Mean & Std. Dev & Remark \\
\hline 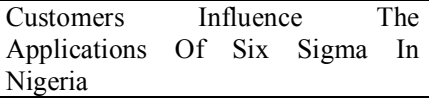 & 380 & 3.87 & 0.827 & Agree \\
\hline $\begin{array}{l}\text { Technological Environment Affects } \\
\text { The Application Of Six Sigma } \\
\text { Strategy In Nigeria }\end{array}$ & 380 & 3.68 & 0.844 & Agree \\
\hline $\begin{array}{l}\text { The Application Of Six Sigma } \\
\text { Strategy Is Influenced By The } \\
\text { Economic Environment }\end{array}$ & 380 & 3.75 & 0.794 & Agree \\
\hline
\end{tabular}




\begin{tabular}{|l|l||l||}
\hline The Legal Cum & Political \\
Environment In Nigeria Influences \\
The Application Of Six Sigma \\
Strategy
\end{tabular}

Source: Survey 2011

From Table 2.1, Since All The Standard Deviations Across The Table Are Relatively Very Small; The Means Can Adequately Be Used To Represent The Data. Hence, We Used The Mean Statistics As The Measure Of Location For The Summary Of Responses. In Summary, The Respondents Agreed, With A Mean Value Of 3.87, That Customers Influence The Applications Of Six Sigma In Nigeria. Similarly, The Respondents Also Agreed, With A Mean Value Of 3.68, That Technological Environment Affects The Application Of Six Sigma Strategy In Nigeria And So Forth As Shown In Table 2.1.

\section{Testing Research Hypothesis}

The Inferential Statistics Presented Below Were Used To Test The Third Research Hypothesis At The 5\% Level Of Significance. Hence, We Want To Investigate Whether The Environmental Factors Do Not Positively Affect The Six Sigma Strategy In Nigeria. In Order To Achieve This Objective, We Use The ChiSquared Test Of Independence With Nominal Correlations. The Chi-Squared Test And The Nominal Correlations Proceed As Follows:

\section{Hypothesis}

$\mathbf{H}_{\mathbf{0}}$ : The Environmental Factors Do Not Positively Affect The Six Sigma Strategy In Nigeria.

$\mathbf{H}_{1}$ : The Environmental Factors Positively Affect The Six Sigma Strategy In Nigeria.

Level Of Significance:

$\alpha=0.05$

Test Statistic:

$$
\chi^{2}=\sum_{i=1}^{r} \sum_{j=1}^{c} \frac{\left(O_{i j}-e_{i j}\right)^{2}}{e_{i j}}
$$

Where; $\quad O_{i j} \quad$ Are The Observed Cell Frequencies

$$
E_{i j} \quad \text { Are The Expected Cell Frequencies }
$$

Decision Criterion:

Reject $H_{0}$ If $p<0.05$ Otherwise Accept $H_{0}$

Computations:

The Computations Are Summarized In The Following Spss Contingency, Chi-Square And Correlation Tables:

Table 3.1: Contingency Table For Adoption Of Six Sigma And Technological Environment

Source: Survey 2011

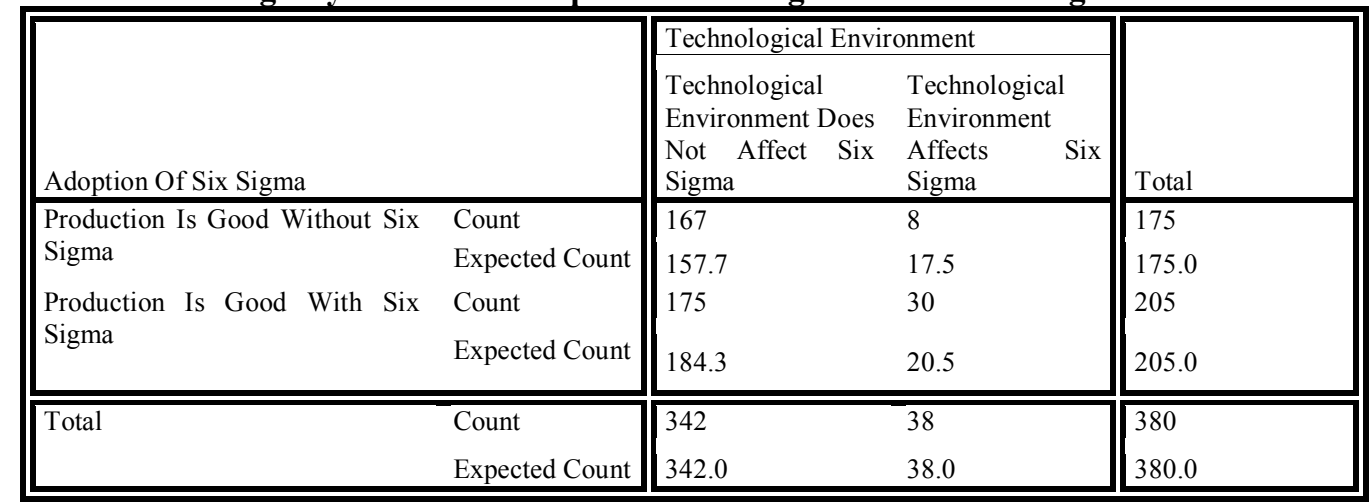

Table 3.2: Chi-Square Tests

\begin{tabular}{||l|lll|}
\hline Test Statistics & Value & Df & Asymp. Sig. (2-Sided) \\
\hline Pearson Chi-Square & 4.583 & 1 & 0.034 \\
Continuity Correction & 3.584 & 1 & 0.058 \\
Likelihood Ratio & 4.883 & 1 & 0.028 \\
\hline N Of Valid Cases & 380 & & \\
\hline
\end{tabular}

Source: Survey 2011 
Table 3.3: Correlation Measures

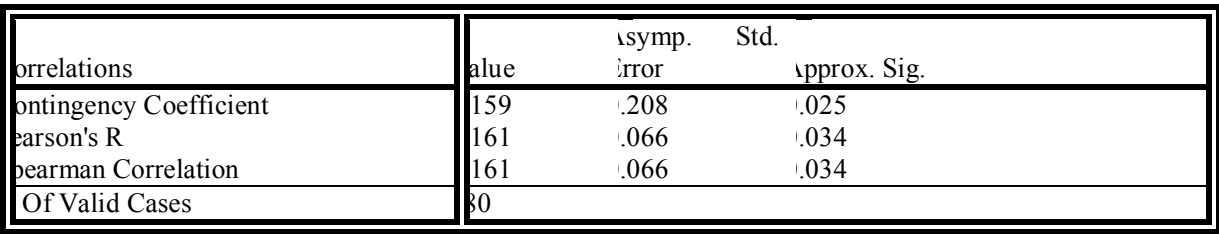

Source: Survey 2011

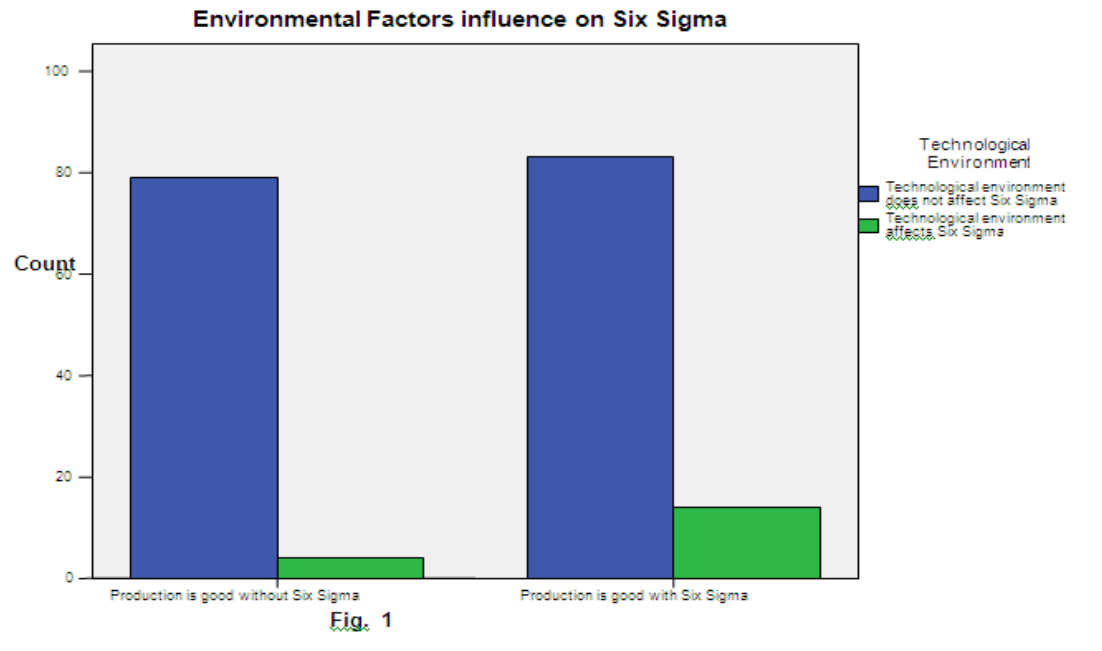

\section{Conclusion For Chi-Square Test}

The Observed And Expected Frequencies Are Displayed In Contingency Table 3.1 As A Process Of Calculating The Chi-Square Statistic And The Nominal Correlations. While The Chi-Square Test Statistic Is In Table 3.2. Moreover, The Correlation Measures Are Also Displayed In Table 3.3. From Table 3.2, For The ChiSquare Statistic, Since $p=0.034<0.05$ We Therefore Reject The Null Hypothesis And Conclude That The Environmental Factors Positively Affect The Six Sigma Strategy In Nigeria. In Other Words, The Six Sigma Strategy Could Be Better Implemented And Better Results Achieved When Environment Is Conducive Than When It Is Not. Furthermore, Table 3.3 Shows The Respective Nominal And Symmetric Correlation Measures Between Environmental Factors Positively And The Implementation Of Six Sigma Strategy In Nigeria; Which Are Both Weak And Significant With Values 0.159 And 0.161. In General, The Implementation Of Six Sigma Strategy Has A Positive Relationship With Some Environmental Factors. This Can Be Shown In The Clustered Bar Chart In Figure 1.

\section{Discussion Of Results}

The Effect Of Environmental Factors On The Application Of Six Sigma Strategy In Nigeria Was Also Determined.

\section{Hypothesis:}

The Environmental Factors Do Not Positively Affect The Six Sigma Strategy In Nigeria.

The Observed And Expected Frequencies Are Displayed In Contingency Table 3.1 As A Process Of Calculating The Chi-Square Statistic And The Nominal Correlations. While The Chi-Square Test Statistic Is In Table 3.2. Moreover, The Correlation Measures Are Also Displayed In Table 3.3. From Table 3.2, For The ChiSquare Statistic, Since $p=0.034<0.05$ We Therefore Reject The Null Hypothesis And Conclude That The Environmental Factors Positively Affect The Six Sigma Strategy In Nigeria. In Other Words, The Six Sigma Strategy Could Be Better Implemented And Better Results Achieved When Environment Is Conducive Than When It Is Not. In General, The Implementation Of Six Sigma Strategy Has Underlying Positive Relationship With Some Environmental Factors.

This Result Confirm The Report Of (Beer Et Al 2005) That Organizations That Make Appropriate And Aligned Internal And External Innovations Are Successful; They Are Able To Take Advantage Of Environmental Opportunities And Survive Environmental Challenges Including Competition, Those Organizations That Fail To Update Their Routines Decline And Get Winnowed Out. This Report Is Further 
Confirmed By (Bhuiyan And Baghel 2005) That The Role Of Six Sigma Has Evolved In Response To New Environmental Challenges Faced By Organizations.

Additional Evidence Is Given By (Cole, 2002) That A Vast Increase In The Speed And Intensity Of Environmental Changes Has Resulted In Expanding The Objectives Of Continuous Improvement Initiatives. It Also Agree With (Grant, 1991) That An Analysis Of The Environment Is Important Because It Increases The Quality Of Strategic Decision Making By Considering A Range Of The Relevant Features Well Before The Need To Make An Irrevocable Decision. The Organization Identifies The Threats And Opportunities Facing It And Those Factors That Might Assist In Achieving Objectives And Those That Might Act As A Barrier. The Strategy Of The Organization Should Be Directed At Exploiting The Environmental Opportunities And To Blocking Environmental Threats In A Way That Is Consistent With Internal Capabilities.

\section{Conclusion}

The Study Examines Six Sigma And Business Environment In Nigeria. Based On The Findings Of The Study, It Is Concluded That The Environmental Factors Positively Affect The Six Sigma Strategy In Nigeria. In Others, The Six Sigma Strategy Could Be Better Implemented And Better Result Achieved When Environment Is Conducive Than When It Is Not.

\section{Recommendations}

Based On The Findings, The Paper Recommends That:

The Business Community In Collaboration With Core Professionals, In The Nation Manufacturing, Banking, Oil And Gas Sector And All Major Stake Holders Should Organize Seminar, Workshops And Conferences On Six Sigma Processes And Its Application. This Will Help Both The Owners Of The Business And Their Customers To Understand And Appreciate The Process.

Government Should Create A Conducive Environment In Relations To Infrastructure Development

And Guided Monetary And Fiscal Policy, For The Industry In Order To Have Competitive Advantage.

Constant Review Or Scanning Of The Environment Should Be Encouraged To Avoid The Unforeseeable Troubles.

\section{References}

[1]. Beer, M.. Voelpel. S. C.: Leihold. M., \& Tekie. K. Ii. (2005). Strategic Management As Organizational Learning: Developing Fit And Alignment Through A Disciplined Process. Long Range Planning. 38(5).

[2]. Betts, M. (1994) "Reengineering Construction : A New Management Research Agenda", Construction Management And Economic, Vol. 4.

[3]. Bhuiyan, N. \& Baghel, A. (2005). An Overview Of Continuous Improvement: From The Past To The Present. Management Decision, 43(5).

[4]. Boer, H. \& Gertsen, F. (2003). From Continous Improvement To Continous Innovation: A (Retro) (Per)Spective. International Journal Of Technology Management, 26(8).

[5]. Brown. S. \& Blackmon, K. (2005). Aligning Manufacturing Strategy And Business-Level Competitive Strategy In New Competitive Environments: The Case For Strategic Resonance. Journal Of Management Studies, 42(4).

[6]. Cole, R.E (2002). From Continuous Improvement To Continuous Innovation. Total Quality Management, 13(8).

[7]. David, F.R. (1989) "How Companies Define Their Mission" Long Range Planning, Vol. 22, No. 1.

[8]. De Foe, J.A., \& Barnard, W.W. (2004). Juran Institute's Six Sigma: Breakthrough And Beyond. New York: Mcgraw-Hill.

[9]. Drucker, P.F. (1993). Post Capitalist Society, Harper Business.

[10]. Drury, C (1988) Management And Cost Accounting ( $2^{\text {nd }}$ Ed.), International Oxford, London.

[11]. Elenkov, D. S. (1997). Strategic Uncertainty And Environmental Scanning: The Case For Institutional Influences On Scanning Behavior. Strategic Management Journal, 18(4).

[12]. Freilich M. (1971) The Meaning Of Culture: A Reader In Cultural Anthropology. Lexingtom, Kentucky: Xerox College Publishing.

[13]. Goeke, R.J., \& Offodile, O.F. (2005). Forecasting Management Philosophy Life Cycles: A Comparative Study Of Six Sigma And Tqm. Quality Management Journal, 12(2).

[14]. Grant, A.K. (1995). Organizational Learning: Medical Metaphor And Corporate Practice. In S. Chawla, \& R.J. Portland (Eds.), Learning Organizations: Developing Cultures For Tomorrow's Workplace (Pp. 445-462). Portland, Or: Productivity Press.

[15]. Grant, R.M. (1996). Prospering In Dynamically-Competitive Environments: Organizational Capability As Knowledge Integration. Organization Science, 7(4).

[16]. Handy, C (1991) “The Age Of Unreason, Century Business" Harvard Business

[17]. Hayes, R. H. \&; Pisano, G. P. (1994). Beyond World-Class: The New Manufacturing Strategy.

[18]. Imaga, E.U.L. (2000) A Manual On Corporate Planning And Strategic Business Policy, Rhyce Kerex Enugu.

[19]. Iweala O.N (2004) "How To Spur Reforms And Improve Outcome" Address Presented By Hon. Minster Of Finance At Around Table Economic Summit.

[20]. Konter, M. (1995) The Change Masters, ( $3^{\text {rd }}$ Edition) Prentice Hall London.

[21]. Mohammed, S. (1998) The Rap On Reengineering Computers World, Macmillan.

[22]. Muhammed S And Tucker S.N (1996) “Construction Process Reengineering”, Building Economist Vol 4.

[23]. Pande, P.S., Neuman, R.P., Cavanagh, R.R., 2002. The Six Sigma Way, Team Fieldbook: An Implementation Guide For Process Improvement Teams. Mcgraw-Hill, New York, Ny..

[24]. Thomas, C.I. (1994) "Strategy In Action”, Chapman And Hall, Retrieved From Uuu.Thomp-Publiedu.Com 